\title{
Pengaruh Model Pembelajaran Visualization Auditory Kinestetic Berbantuan Mutimedia Interaktif Terhadap Kompetensi Pengetahuan IPA
}

\author{
K. D. R. Widiartha1 ${ }^{*}$, I. B. S. Manuaba², DB.Kt. Ngr. Semara Putra3 \\ 1 Jurusan PGSD Universitas Pendidikan Ganesha Singaraja, Indonesia \\ 2 Jurusan PGSD Universitas Pendidikan Ganesha Singaraja, Indonesia \\ ${ }^{3}$ Jurusan PGSD Universitas Pendidikan Ganesha Singaraja, Indonesia
}

\begin{abstract}
Abstrak
Penelitian ini bertujuan untuk mengetahui pengaruh Model Pembelajaran Visualization Auditory Kinestetic Berbantuan Multimedia Interaktif terhadap Kompetensi Pengetahuan IPA siswa kelas V SD Gugus Dewi Sartika Tahun Pelajaran 2017/2018. Jenis penelitian ini adalah eksperimen semu (quasi ekperimen) dengan rancangan penelitian Non-Equivalen Control Grup Design. Populasi seluruh siswa kelas V SD Gugus Dewi Sartika Kecamatan Denpasar Timur yang berjumlah 327 siswa. Sampel ditentukan menggunakan teknik random sampling dengan melakukan pengundian. Sampel dalam penelitian ini yaitu SDN 16 Kesiman sebagai kelas eksperimen yang berjumlah 37 siswa dan SDN 12 Kesiman sebagai kelas kontrol yang berjumlah 34 siswa. Data kompetensi pengetahuan IPA di kumpulkan dengan metode tes yang kemudian dianalisis menggunakan uji-t. Hasil analisis diperoleh thitung $=4,953$, dan pada taraf signifikasi $5 \%$ dan derajat kebebasan $(\mathrm{dk})=37+34-2$ $=69$ maka diperoleh harga ttabel $=2,000$. Berdasarkan hasil tersebut, thitung $=4,953$ $>$ ttabel $=2,000$. H0 di tolak yang berarti terdapat perbedaan yang signifikan kompetensi pengetahuan IPA antara kelompok eksperimen yang dibelajarkan melalui Model Pembelajaran Visualization Auditory Kinestetic berbantuan Multimedia Interaktif dengan kelompok kontrol pada kelas V SD Gugus Dewi Sartika Tahun Pelajaran 2017/2018. Hasil penelitian menunjukan nilai rata-rata kelompok eksperimen lebih tinggi daripada nilai rata-rata kelompok kontrol $(87,30>73,53)$. Dengan demikian, Model Pembelajaran Visualization Auditory Kinestetic berbantuan Multimedia Interaktif berpengaruh terhadap kompetensi pengetahuan IPA siswa kelas V SD Gugus Dewi Sartika Kecamatan Denpasar Timur Tahun Pelajaran $2017 / 2018$.
\end{abstract}

\author{
Keywords: \\ Visualization Auditory \\ Kinestetic, Multimedia \\ Interaktif, Kompetensi \\ pengetahuan IPA.
}

\section{PENDAHULUAN}

Pendidikan merupakan sarana penting untuk meningkatkan kualitas Sumber Daya Manusia (SDM) dalam menjamin keberlangsungan pembangunan suatu bangsa. Peningkatan kualitas SDM jauh lebih mendesak untuk segera direalisasikan terutama dalam menghadapi era persaingan global. Peningkatan kualitas SDM sejak dini merupakan hal penting yang harus dilakukan secara sungguh.

Pada kurikulum 2013 dikembangan dengan tujuan mewujudkan tujuan pendidikan nasional, yaitu "Berkembangnya potensi peserta didik agar menjadi manusia yang beriman dan bertaqwa kepada Tuhan Yang Maha Esa, berahlak mulia, sehat, berilmu, cakap, kreatif, mandiri, dan menjadi warga negara yang demokratif serta bertanggung jawab" (Sani, 2014:vii). Pengembangan potensi peserta didik harus dilakukan secara bertahap sesuai dengan perkembangan psikologi peserta didik sehingga pendidikan pada tingkat sekolah dasar fokus pada pengembangan sikap dan perilaku. Peserta didik harus dibimbing untuk mengenal potensinya sejak dini dan mampu mengembangkan potensi tersebut dengan bantuan guru sehingga dapat menjadi generasi yang mampu memberikan kontribusi yang signifikan bagi kemajuan bangsa dan negara. 
Kunci keberhasilan dari upaya tersebut tidak lepas dari peran seorang guru dan kemampuannya dalam merancang, melaksanakan, dan mengevaluasi kegiatan pembelajaran. Menurut UU No. 14 Tahun 2005 pasal 1 tentang guru dan dosen "Guru adalah pendidik profesional dengan tugas utama mendidik, mengajar, membimbing, mengarahkan, melatih, menilai, dan mengevaluasi peserta didik pada pendidikan anak usia dini jalur pendidikan formal, pendidikan dasar, dan pendidikan menengah". Berkaiatan dengan tugas guru, maka dalam merencanakan suatu pembelajaran diharapkan mampu menciptakan pembelajaran yang menarik dan menyenangkan, sehingga peserta didik menjadi senang mengikuti setiap proses pembelajaran. Dengan demikian peserta didik dapat memahami pelajaran pada setiap bidang ilmu pengetahuan, salah satunya IPA.

Hal ini terbukti dari hasil observasi yang dilakukan pada tanggal 17 Januari 2018 dengan guru wali kelas V di masing-masing SD Gugus Dewi Sartika, Kecamatan Denpasar Timur Tahun Pelajaran 2017/2018, untuk kompetensi pengetahuan pada pelajaran Ilmu Pengetahuan Alam diperoleh dari nilai Ulangan Akhir Semester I yaitu, dari 327 sebanyak 137 siswa atau 41,89 \% yang sudah mencapai nilai yang diharapkan. Sedangkan, 190 siswa atau 58,10 \% yang belum mencapai nilai yang diharapkan.

Model pembelajaran Visualization Auditory Kinestetic merupakan alternatif baru yang dimodifikasi dengan modalitas yang dimiliki oleh siswa. Dalam penerapannya di kelas memiliki kelebihan yaitu dapat mengaitkan pengalaman siswa dengan bantuan modalitas yang ada pada diri siswa yaitu penglihatan (visualization), pendengaran (auditory), dan gerakan tubuh (Kinestetic). Model ini memberikan kesempatan kepada siswa untuk belajar langsung dengan bebas menggunakan modalitas yang dimilikinya untuk mencapai pemahaman dan pembelajaran yang efektif (Ariastini, 2013). Model pembelajaran Visualization Auditory Kinestetic adalah model pembelajaran yang mengoptimalkan ketiga modalitas belajar tersebut untuk menjadikan belajar merasa nyaman. Model pembelajaran Visualization Auditory Kinestetic merupakan anak dari model pembelajaran Quantum yang berprinsip untuk menjadikan situasi belajar menjadi lebih nyaman dan menjadikan kesuksesan bagi pembelajarnya di masa depan.

Visualization Auditory Kinestetic merupakan tiga modalitas yang dimiliki oleh setiap manusia. Ketiga modalitas tersebut kemudian dikenal sebagai gaya belajar. " Gaya belajar adalah kombinasi dari bagaimana menyerap, lalu mengatur, dan mengolah informasi” (Depotter, 2016:111).

Selain itu, penggunaan multimedia interaktif sangat berperan penting karena semakin sadarnya orang akan pentingnya media yang dapat membantu proses pembelajaran yang sudah mulai dirasakan. Dengan semakin meluasnya kemajuan bidang teknologi informasi dan komunikasi, maka pelaksanaan kegiatan pendidikan dan pembelajaran semakin menuntut dan memperoleh media pembelajaran yang bervariasi secara luas. Secara estimalogis multimedia berasal dari bahasa latin, yaitu kata "multi" yang berarti banyak, bermacam-macam, dan "medium" yang berarti sesuatu yang digunakan untuk menyampaikan atau membawa sesuatu. (Wijaya, 2017) Multimedia merupakan perpaduan berbagai bentuk elemen informasi yang digunakan sebagai sarana menyampaikan tujuan tertentu. Elemen informasi yang dimaksud di antaranya teks, grafik, gambar, foto, animasi, audio, video. Dalam penggunaannya multimedia terbagi dalam dua kategori, yaitu multimedia linier dan multimedia interaktif. Multimedia linier merupakan suatu multimedia yang tidak dilengkapi dengan alat pengontrol apapun yang dapat dioperasikan oleh pengguna. Multimedia ini berjalan lurus atau berurutan. Sebagai contoh adalah Televisi dan Film. Sedangkan multimedia interaktif adalah suatu multimedia yang dilengkapi dengan alat pengontrol yang dioperasikan oleh pengguna, sehingga pengguna dapat memilih apa yang dikehendaki untuk proses selanjutnya. Contohnya seperti aplikasi game. Multimedia interaktif menggabungkan dan mensinergikan semua media yang terdiri dari teks, grafik, audio, dan interaktivitas atau rancangan (Sumardika, 2014).

Model Pembelajaran Visualization Auditory Kinestetic berbantuan Multimedia Interaktif diharapkan dapat berpengaruh kepada siswa, agas siswa lebih termotivasi dalam proses pembelajaran, dan minat siswa dalam mengikuti pembelajaran menjadi lebih baik dan menyenangkan. Karena Model Pembelajaran Visualization Auditory Kinestetic dapat memacu siswa dalam mengeksplorasi ide-idenya dengan cara melihat, mendengar, dan langsung mempraktekan apa yang dilihat, dan apa yang didengar, dengan begitu akan tumbuh rasa percaya diri siswa. Selain itu Model Pembelajaran Visualization Auditory Kinestetic dipadukan dengan Multimedia Interaktif yang berupa presentasi yang dimana dalam presentasi berisi tentang materi pembelajaran, dan video pembelajaran. Dengan begitu siswa akan lebih termotivasi dan beminat untuk mengikuti pembelajaran.

Dari uraian tersebut model pembelajaran Visualization Auditory Kinestetic berbantuan Multimedia Interaktif dapat memberikan pengaruh bagi Kompetensi Pengetahuan IPA siswa. Apabila Model Pembelajaran Visualization Auditory Kinestetic berbantuan Multimedia Interaktif dilaksanakan dengan baik dan benar, maka dapat menumbuhkan sikap percaya diri, minat siswa menjadi lebih meningkat dalam mengikuti pembelajaran, dan juga siswa akan lebih termotivasi untuk belajar sehingga, Model Pembelajaran Visualization Auditory Kinestetic berbantuan Multimedia Interaktif diharapkan 
berpengaruh terhadap kompetensi pengetahuan IPA siswa di SD Gugus Dewi Sartika Tahun Pelajaran $2017 / 2018$.

\section{METODE PENELITIAN}

Penelitian ini merupakan penelitian kuantitatif dengan jenis penelitian eksperimen semu (quasi ekperimen) dengan populasi seluruh siswa kelas V SD Gugus Dewi Sartika Kecamatan Denpasar Timur yang berjumlah 327 siswa. Sampel ditentukan dengan menggunakan teknik random sampling dengan mengundi kelas. Sampel dalam penelitian ini yaitu SDN 16 Kesiman sebagai kelas eksperimen yang berjumlah 37 siswa dan SDN 12 Kesiman sebagai kelas kontrol yang berjumlah 34 siswa. Data hasil kompetensis pengetahuan IPA dikumpulkan dengan instrumen berupa tes objektif bentuk pilihan ganda biasa berjumlah 33 butir tes yang telah divalidasi.

Setelah diberikan perlakuan sebanyak 6 kali, pada akhir eksperimen kedua sampel kelompok diberikan post test untuk memperoleh data kompetensi pengetahuan IPA. Berdasarkan hasil analisis data kompetensi pengetahuan IPA pada kelompok eksperimen mendapatkan nilai rata-rata $=87,30$ sedangkan pada kelompok kontrol mendapatkan nilai rata-rata $=73,53$. Hasil uji normalitas sebaran data kompetensi pengetahuan IPA pada kelompok eksperimen dan kelompok kontrol berdistribusi normal dan pada uji homogenitas varians menunjukan data kompetensi pengetahuan IPA kedua kelompok mempunyai varian homogen.

Data yang diperoleh telah memenuhi uji prasyarat analisis. Berdasarkan hal tersebut dilakukan analisis uji hipotesis dengan uji t. Hasil analisis tersebut menunjukan bahwa terdapat perbedaan yang signifikan kompetensi pengetahuan IPA siswa antara kelompok eksperimen dengan kelompok kontrol. Dengan demikian, dapat disimpulkan bahwa Model Pembelajaran Visualization Auditory Kinestetic berbantuan Multimedia Interaktif berpengaruh terhadap kompetensi pengetahuan IPA siswa kelas V di SD Gugus Dewi Sartika Tahun pelajaran 2017/2018.

\section{ANALISIS DAN PEMBAHASAN}

Pelaksanaan pembelajaran di dalam kelas selama ini secara umum telah berlangsung sesuai dengan rencana pelaksanaan pembelajaran yang telah disusun sebagai penerapan model pembelajaran Visualization Auditory Kinestetic Berbantuan Multimedia Interaktif di kelas V SDN 16 Kesiman ditetapkan sebagai kelompok eksperimen yang diberi perlakuan sebanyak 6 kali pertemuan, selanjutnya diberikan post test untuk memeroleh hasil kompetensi pengetahuan IPA.

Nilai mean atau rata-rata kompetensi pengetahuan IPA siswa yang mengikuti pembelajaran menggunakan model pembelajaran Visualization Auditory Kenistetic, kelompok eksperimen $\left(\overline{X_{1}}\right)=$ 87,30 serta berdasarkan perhitungan diperoleh varians kompetensi pengetahuan IPA kelompok eksperimen $\left(\mathrm{S}_{1}{ }_{1}\right)=118,16$. Sementara itu, berdasarkan perhitungan diperoleh rerata kompetensi pengetahuan IPA kelompok kontrol $\left(\overline{X_{2}}\right)=73,53$ serta berdasarkan perhitungan diperoleh varians kompetensi pengetahuan IPA kelompok kontrol $\left(\mathrm{S}_{2}{ }_{2}\right)=160,01$. Perhitungan analisis data hasil penelitian yang diperoleh menunjukkan bahwa kompetensi pengetahuan IPA kelompok eksperimen memiliki nilai mean lebih tinggi daripada kelompok kontrol yaitu $\bar{X}=87,30>\bar{X}=73,53$.

Sebelum menggunakan uji-t untuk menganalisis uji hipotesis, dilakukan terlebih dahulu uji prasyarat. Uji prasyarat tersebut meliputi uji normalitas dan uji homogenitas varians yang diuraikan berikut ini. Uji normalitas sebaran data dilakukan pada post test hasil kompetensi pengetahuan IPA. Untuk mengetahui sebaran data berdistribusi normal atau tidak dapat digunakan analisis Chi Kuadrat. Dengan kriteria taraf signifikansinya adalah 5\% dengan derajat kebebasan $(\mathrm{dk})=$ jumlah baris $(\mathrm{k})-1$. Kriteria pengujian adalah jika $X_{\text {hit }}^{2}<X_{\text {tabel }}^{2}$, maka $\mathrm{f}_{\mathrm{o}}$ diterima (gagal ditolak) yang berarti data berdistribusi normal. Bila $X_{\text {hit }}^{2}>X_{\text {tabel }}^{2}$ maka data tidak berdistribusi normal. Berdasarkan hasil analisis diperoleh $\mathrm{X}^{2}$ hitung $=5,51$ untuk siswa kelompok eksperimen. Nilai tersebut dikonsultasikan dengan $\mathrm{X}^{2}$ tabel dengan $\mathrm{dk}=$ 5 pada taraf signifikansi $5 \%$ sehingga diperoleh $\mathrm{X}^{2}$ tabel $=11,07$. Setelah pengujian dilakukan diperoleh $\mathrm{X}_{\text {hitung }}=5,51<\mathrm{X}_{\text {tabel }}=11,07$, hal tersebut menyatakan bahwa data kompetensi pengetahuan IPA siswa kelas V kelompok Eksperimen berdistribusi normal.

Berdasarkan hasil analisis diperoleh $\mathrm{X}^{2}$ hitung $=6,61$ untuk siswa kelompok kontrol. Nilai tersebut dikonsultasikan dengan $\mathrm{X}^{2}$ tabel dengan $\mathrm{dk}=5$ pada taraf signifikansi 5\% sehingga diperoleh $\mathrm{X}^{2}$ tabel $=11,07$. Setelah pengujian dilakukan diperoleh $\mathrm{X}^{2}$ hitung $=6,61<\mathrm{X}^{2}$ tabel $=11,07$, hal tersebut menyatakan bahwa data kompetensi pengetahuan IPA siswa kelas V kelompok Kontrol berdistribusi normal. 
Perolehan data hasil pengujian homogenitas data kompetensi pengetahuan IPA kelompok eksperimen dan kelompok kontrol memperoleh $\mathrm{F}_{\text {hitung }}=1,42$. Nilai tersebut kemudian dikonsultasikan dengan $\mathrm{F}_{\text {tabel }}$ pada taraf signifikasi 5\% dengan derajat kebebasan (dk) 33,36 adalah 1,78 yang berarti $\mathrm{F}_{\text {hitung }}<\mathrm{F}_{\text {tabel }}$ maka dapat disimpulkan bahwa data kompetensi pengetahuan IPA siswa pada kedua kelompok tersebut mempunyai varian yang homogen. Pengujian homogenitas Berdasarkan hasil uji prasyarat yang terdiri dari uji normalitas dan uji homogenitas varians, disimpulkan bahwa data kedua kelompok sampel ialah berdistribusi normal dan memiliki varians yang homogen. Dengan demikian, uji hipotesis menggunakan uji-t dapat dilakukan.

Hipotesis yang diuji dalam pe-nelitian ini adalah Tidak terdapat perbedaan yang signifikan kompetensi pengetahuan IPA antara kelompok eksperimen yang dibelajarkan melalui Model Pembelajaran Visualization Auditory Kinestetic berbantuan Multimedia Interaktif dengan kelompok kontrol pada kelas V SD Gugus Dewi Sartika, Denpasar Timur.

Hasil analisis uji $\mathrm{t}$ diperoleh $\mathrm{t}_{\text {hitung }}=4,953$. Pada taraf signifikasi $5 \%$ dan derajat kebebasan $(\mathrm{dk})=$ $37+34-2=69$ maka diperoleh harga $t_{\text {tabel }}=2,000$. Berdasarkan hasil tersebut, diperoleh $t_{\text {hitung }}=4,953>$ $\mathrm{t}_{\text {tabel }}=2,000$. Berdasarkan hasil analisis uji $\mathrm{t}$ diperoleh $\mathrm{t}_{\text {hitung }}=4,953>\mathrm{t}_{\text {tabel }}=2,000 \mathrm{maka} \mathrm{H}_{0}$ yang menyatakan tidak terdapat perbedaan yang signifikan kompetensi pengetahuan IPA antara kelompok eksperimen yang dibelajarkan melalui Model Pembelajaran Visualization Auditory Kinestetic berbantuan Multimedia Interaktif dengan kelompok kontrol pada kelas V SD Gugus Dewi Sartika Tahun Pelajaran $2017 / 2018$ ditolak 1. berikut.

Perhitungan.rekapitulasi hasil analisis uji-t kelompok sampel penelitian ini disajikan dalam Tabel

Tabel 1. Rekapitulasi Hasil Aanalisis Data Kompetensi Pengetahuan matematika Menggunakan Uji-t

\begin{tabular}{|c|c|c|c|c|c|c|c|c|}
\hline No & Sampel & $\mathrm{N}$ & Dk & $\bar{X}$ & $\mathrm{~S}^{2}$ & $t_{\text {hitung }}$ & $t_{\text {tabel }}$ & Status \\
\hline 1 & $\begin{array}{l}\text { Kelompok } \\
\text { eksperimen }\end{array}$ & 37 & & 87,30 & 118,16 & & & $\mathrm{H}_{0}$ \\
\hline 22 & Kelompok control & 34 & 69 & 73,53 & 160,01 & 4,953 & 2,000 & ditolak \\
\hline
\end{tabular}

Berdasarkan hasil analisis uji t diperoleh $t_{\text {hitung }}=4,953$. Pada taraf signifikasi $5 \%$ dan derajat kebebasan $(\mathrm{dk})=37+34-2=69$ diperoleh harga $t_{\text {tabel }}=2,000$. Dengan demikian diperoleh $t_{\text {hitung }}=4,097>$ $t_{\text {tabel }}=2,000$. Maka $\mathrm{H}_{0}$ ditolak. Hal ini berarti terdapat perbedaan yang signifikan kompetensi pengetahuan IPA antara kelompok eksperimen yang dibelajarkan melalui Model Pembelajaran Visualization Auditory Kinestetic berbantuan Multimedia Interaktif dengan kelompok kontrol pada kelas V SD Gugus Dewi Sartika Tahun Pelajaran 2017/2018. Perolehan hasil perhitungan analisis data yang dilakukan menunjukan bahwa nilai rata-rata siswa yang mengikuti Model Pembelajaran Visualization Auditory Kinestetic berbantuan Multimedia Interaktif (nilai rata-rata $=87,53$ ) dan siswa yang tidak mengikuti pembelajaran Model Pembelajaran Visualization Auditory Kinestetic berbantuan Multimedia Interaktif (nilai rata-rata $=73,53$ ) memiliki perbedaan sebesar 13,77. Dengan demikian, terdapat pengaruh Model Pembelajaran Visualization Auditory Kinestetic berbantuan Multimedia Interaktif terhadap Kompetensi IPA Kelas V SD Gugus Dewi Sartika Tahun Pelajaran 2017/2018.

Berdasarkan hasil analisis uji $t$ diperoleh $t_{\text {hitung }}=4,953$. Pada taraf signifikasi $5 \%$ dan derajat kebebasan $(\mathrm{dk})=37+34-2=69$ diperoleh harga $t_{\text {tabel }}=2,000$. Dengan demikian diperoleh $t_{\text {hitung }}=4,953>$ $t_{\text {tabel }}=2,000$. Maka $\mathrm{H}_{0}$ ditolak. Hal ini berarti terdapat perbedaan yang signifikan kompetensi pengetahuan IPA antara kelompok eksperimen yang dibelajarkan melalui Model Pembelajaran Visualization Auditory Kinestetic berbantuan Multimedia Interaktif dengan kelompok kontrol pada kelas V SD Gugus Dewi Sartika Tahun Pelajaran 2017/2018.

Pada kelompok eksperimen, kegiatan pembelajaran dalam pelajaran IPA menggunakan Model Pembelajaran Visualization Auditory Kinestetic berbantuan Multimedia Interaktif berjalan dengan lancar, baik, dan kondusif. Hal ini disebabkan oleh Model Pembelajaran Visualization Auditory Kinestetic berbantuan Multimedia Interaktif merupakan suatu inovasi pembelajaran yang dapat menumbuhkan minat, motivasi, dan sikap percaya diri siswa dalam proses pembelajaran karena model pembelajaran ini mengkombinasikan tiga modalitas yang dimiliki oleh manusia yaitu penglihatan, pendengaran, dan gerakan tubuh. Pembelajaran akan menjadi lebih menarik dan menyenangkan serta dapat meningkatkan motivasi siswa karena dikemas dalam kegiatan pembelajaran yang meliputi kiat-kiat, petunjuk, strategi, dan seluruh proses belajar yang dapat mempertajam daya ingat, serta memjadikan belajar sebagai suatu 
proses yang menyenangkan, bermanfaat, dan bermakna. Dengan demikian siswa lebih dapat memahami materi yang diberikan dan mengaplikasikan dalam kehidupan sehari-hari. Selain itu, Model Pembelajaran Visualization Auditory Kinestetic Berbantuan Multimedia Interaktif digunakan untuk pembelajaran, pemrosesan, dan komunikasi. Bahkan beberapa orang tidak cenderung kepada satu modalitas saja, namun bisa memanfaatkan kombinasi modalitas tertentu untuk meningkatkan kemampuan belajar. Visualization Auditory Kinestetic merupakan tiga modalitas yang dimiliki oleh setiap manusia. Ketiga modalitas tersebut kemudian dikenal sebagai gaya belajar. Depotter, 2016:111 menyatakan " Gaya belajar adalah kombinasi dari bagaimana menyerap, lalu mengatur, dan mengolah informasi”. Adapun kelebihan dari model pembelajaran Visualization Auditory Kinestetic berbantuan Multimedia Interaktif adalah sebagai berikut. (Shoimin,2014:228) a) Pembelajaran akan lebih efektif karena mengkombinasikan ketiga gaya belajar serta pembelajaran menjadi lebih inovatif dan interaktif, b) Mampu melatih dan mengembangkan potensi siswa yang telah dimiliku oleh pribadi masing-masing dan juga dapat memotivasi belajar siswa, c) Mampu melibatkan siswa secara maksimal dalam menemukan dan memahami suatu konsep melalui kegiatan fisik, seperti demonstrasi, percobaan, observasi, dan diskusi aktif dan dapat menggabungkan antara teks, gambar, audio, musik, animasi gambar, atau video dalam satu kesatuan yang saling mendukung. Hal tersebut didukung hasil penelitian yang relevan yang dilakukan oleh Ariastini (2013) dan Suryantini (2017) yang memperoleh data hasil kompetensi pengetahuan IPA siswa kelompok eksperimen lebih tinggi dari data hasil Kompetensi pengetahuan IPA siswa kelompok kontrol.

Dengan demikian, pembelajaran menggunakan Model Pembelajaran Visualization Auditory Kinestetic berbantuan Multimedia Interaktif pada penelitian ini memiliki keunggulan yakni dapat meningkatkan kompetensi pengetahuan IPA dan meningktkan minat, motivasi, serta sikap percaya diri siswa.

\section{KESIMPULAN}

Berdasarkan hasil pembahsan dan analisi dapat disimpulkan bahwa Model Pembelajaran Visualization Auditory Kinestetic berbantuan Multimedia Interaktif berpengaruh terhadap kompetensi pengetahuan IPA siswa kelas V di SD Gugus Dewi Sartika Tahun pelajaran 2017/2018. Hal ini dibuktikan dengan analisis uji t diperoleh thitung $=4,953$. Pada taraf signifikasi $5 \%$ dan derajat kebebasan $(\mathrm{dk})=$ $37+34-2=69$ maka diperoleh harga ttabel $=2,000$. Berdasarkan hasil tersebut, diperoleh thitung $=4,953$ $>$ ttabel $=2,000$. Serta rata-rata kompetensi pengetahuan IPA kelompok eksperimen $=87,30$ dan ratarata kompetensi pengetahuan IPA kelompok kontrol $=73,53$.

Berdasarkan pada simpulan penelitian yang diperoleh, maka beberapa saran dapat diajukan kepada beberapa pihak adalah sebagai berikut. 1) Kepala Sekolah, sebaiknya menyediakan fasilitas pembelajaran yang lengkap sehingga siswa dapat menfaatkan fasilitas tersebut dan guru dapat membelajarkan siswa dengan model-model pembelajaran inovatif seperti Model Pembelajaran Visualization Auditory Kinestetic berbantuan Multimedia Interaktif untuk mengoptimalkan kompetensi pengetahuan siswa. 2) Guru, hendaknya menajdikan hasil penelitian ini sebagai bahan pertimbangan dalam menyusun perencanaan pembelajaran karena hasil penelitian ini menunjukan bahwa terdapat pengaruh Model Pembelajaran Visualization Auditory Kinestetic berbantuan Multimedia Interaktif terhadap kompetensi pengetahuan IPA. 3) Peneliti lain, dapat melakukan penelitian lebih lanjut mengenai pengaruh Model Pembelajaran Visualization Auditory Kinestetic berbantuan Multimedia Interaktif pada materi pembelajaran yang berbeda dan pada sampel yang berbeda sehingga hasil penelitian benar-benar menggambarkan keadaan yang sesungguhnya dilapangan.

\section{DAFTAR PUSTAKA}

Agung, A.A. Gede. 2011. Pengantar Evaluasi Pendidikan. Singaraja: Universitas Pendidikan Ganesha.

Agung, A.A. Gede. 2014. Metodologi Penelitian Pendidikan. Singaraja: Universitas Pendidikan Ganesha .

Antari, Suci. 2013. " Pengaruh Pendekatan Pembelajaran Whole Language Berbantuan Multimedia Interaktif Terhadap Hasil Belajar BI Siswa Kelas III SD Gugus V Dr. Soetomo “. Universitas Pendidikan Ganesha. Tersedia Pada http:/ejournal.undiksha.ac.id (Diakses tanggal 20 Januari 2018).

Arikunto, Suharsimi. 2012. Dasar-Dasar Evaluasi Pendidikan. Jakarta: PT Bumi Aksara. 
Ariastini, 2013. “ Pengaruh Model Pembelajaran Kuantum Tipe VAK (Visual Auditory Kinesthetic) Terhadap Hasil Belajar IPA Siswa Kelas V SD Negeri 2 Sesetan”. Universitas Pendidikan Ganesha. Tersedia Pada http:/ejournal.undiksha.ac.id (Diakses tanggal 20 Januari 2018).

Dantes, Nyoman. 2015. Metode Penelitian. Yogyakarta: PT. Rajawali

Deporter, Bobby. 2016. Quantum Learning. Bandung: Kaifa.

Deporter, Bobby. 2010. Quantum Teaching. Bandung: Kaifa.

Dwiyanti, Dewi. 2013. “ Model Pembelajaran VAK Berbantuan VCD Berpengaruh Terhadap Prestasi Belajar Matematika Siswa Kelas IV SD Gugus V Dr. Soetomo ". Universitas Pendidikan Ganesha. Tersedia Pada http:/ejournal.undiksha.ac.id (Diakses tanggal 20 Januari 2018).

Huda, Miftahul. 2013. Model-Model Pengajaran dan Pembelajaran. Yogyakarta: Pustaka Belajar.

Jampel, 2016. Pedoman Penulisan Karya Ilmiah. Singaraja: Universitas Pendidikan Ganesha.

Koyan, Wayan. 2012. Statistik Pendidikan Teknik Analisis Data Kuantitatif. Singaraja: Universitas Pendidikan Ganesha.

Kunandar, 2014. Penilaian Autentik. Jakarta: Rajawali Pers.

Pebrianti, 2013. “ Pengaruh Model Pembelajaran Quantum Tipe VAK Berbantuan Megic Box Terhadap Hasil Belajar IPA Kelas IV SD ".Universitas Pendidikan Ganesha. Tersedia Pada http:/ejournal.undiksha.ac.id (Diakses tanggal 20 Januari 2018).

Sani, Abdullah. 2014. Pembelajaran Saintifik Untuk Kurikulum Implementasi Kurikulum 2013. Jakarta: PT Bumi Aksara.

Sumardika, Putu. 2014. "Penerapan Model Accelerated Learning Berbantuan Multimedia Interaktif Untuk Meningkatkan Aktivitas dan Hasil Belajar IPA Siswa Kelas IV SDN 13 Dauh Puri Denpasar “.Universitas Pendidikan Ganesha. Tersedia Pada http:/ejournal.undiksha.ac.id (Diakses tanggal 20 Januari 2018).

Shoimin, Aris. 2014. 68 Model Pembelajaran Inovatif Dalam Kurikulum 2013. Yogyakarta: Ar-Ruzz Media.

Sumantowa, Usman. 2016. Pembelajaran IPA di Sekolah Dasar. Jakarta: PT Indeks.

Setyosari, Punaji. 2016 Metode Penelitian Pendidikan dan Pengembangan. Malang: Prenadamedia Group.

Sudijono, Anas. 2009. Pengantar Evaluasi Pendidikan. Jakarta: PT Raja Grafindo.

Sugiyono, 2017. Metode Penelitian Kuantitaif Kualitatif dan R\&D. Bandung: Alfabeta.

Sugiyono, 2017. Statistik Untuk Penelitian. Bandung: Alfabeta.

Sukardi, 2017. Metodelogi Penelitian Pendidikan. Yogyakarta: PT Bumi Aksara.

Suryantini, Nanik. 2017. “ Pengaruh Model Pembelajaran Visual Audiotori Kinestetik Berbantuan Media Audio Visual Terhadap Kompetensi Pengetahuan IPA Kelas V SD Gugus Dewi Sartika “.Universitas Pendidikan Ganesha. Tersedia Pada http:/ejournal.undiksha.ac.id (Diakses tanggal 20 Januari 2018).

Wati, Rima. 2016. Ragam Media Pembelajaran. Jakarta: Kata Pena.

Wijaya, Putu. 2017. “ Pengaruh Model Pembelajaran Discovery Learning berbatuan Multimedia Interaktif Terhadap Kompetensi Pengetahuan IPS Kelas V SD Gugus Kompyang Sujana ".Universitas Pendidikan Ganesha. Tersedia Pada http:/ejournal.undiksha.ac.id (Diakses tanggal 20 Januari 2018). 
Wisudawati, Widi dan Sulistyowati, Eka. 2017. Metodelogi Pembelajaran IPA. Jakarta: PT Bumi Aksara.

Yusuf, Muri. 2016. Metode Penelitian Kuantitatif Kualitatif dan Penelitian Gabungan. Jakarta: Prenadamedia Group. 